\title{
QUALITATIVE PHYTOCHEMICAL COMPARISON BETWEEN FLAVONOIDS AND PHENOLIC ACIDS CONTENTS OF LEAVES AND FRUITS OF MELIA AZEDARACH (FAMILY: MELIACEAE) CULTIVATED IN IRAQ BY HPLC AND HPTLC
}

\author{
NOOR S. JAAFAR*, MAHA N. HAMAD*, IBRAHIM S. ABBAS**, IMAN S. JAAFAR*** \\ *Department of Pharmacognosy and Medicinal Plants, College of Pharmacy, University of Baghdad, **Department of Pharmacognosy and \\ Medicinal Plants, College of pharmacy, University of Al-Mustansiriya, ${ }^{* * *}$ Department of Pharmaceutics College of Pharmacy, University of \\ Al-Mustansiriya \\ Email: noorsaldahan@yahoo.com, pharm.eman.aldahan@uomustansiriyah.edu.iq
}

Received: 04 Jul 2016 Revised and Accepted: 23 Aug 2016

ABSTRACT

Objective: The aim of our study was to compare between flavonoids and phenolic acids contents of leaves and fruits of Melia azedarach since no phytochemical investigation had done previously in Iraq.

Methods: The leaves and fruits of Melia azedarach were extracted by soxhlet using $80 \%$ ethanol then the dried extract was suspended in water and fractionated using petroleum ether, chloroform, ethyl acetate, and n-butanol. The n-butanol fraction was hydrolyzed by acid and partitioned with ethyl acetate. The different fractions containing flavonoids and phenolic acids were analyzed by HPLC and HPTLC.

Results: The HPLC results revealed the presence catechin-7-0-glycoside in fruit only, while kaempferol-7-0-glycoside is found in the leaves only. Catechin and its glycosides are more abundant in the fruits than in the leaves. The HPTLC results revealed that kaempferol and quercetin are present in all fractions of leaves and fruits as aglycones and as glycosides. Free chlorogenic was found in both leaves and fruits.

Conclusion: No major differences were found between the flavonoids and phenolic acids contents of the leaves and fruits of Melia azedarach.

Keywords: Melia azedarach L, Flavoniods, HPLC, HPTLC

(C) 2016 The Authors. Published by Innovare Academic Sciences Pvt Ltd. This is an open access article under the CC BY license (http://creativecommons.org/licenses/by/4. 0/) DOI: http://dx.doi.org/10.22159/ijpps.2016v8i10.13868

\section{INTRODUCTION}

Melia azedarach also known as Chinaberry, umbrella tree, white cedar and Persian lilac is an important medicinal plant which belongs to Meliaceae family [1]. It is a deciduous small to medium size, shade tree with a rounded crown can reach a height of 5-15 meter at maturity having a width of 5-7 meters [2]. The plant has an average lifespan about $20 \mathrm{y}$ [3]. It is excessively distributed in tropical and subtropical countries, native to South-East Asia and Australia [4]. It contains many phytochemical compounds like alkaloids, tannins, saponins, phenols, glycosides, steroids, terpenoids and flavonoids $[5,6]$.

Leaves and fruits of M. azedarach have anti-fee dent activity and used in pest control due to biologically active triterpenoids such as azadirachtin with an anti-alimentary effect $[7,8]$. The plant show antipyretic activity [9], antiviral activity due to meliacarpin [10], antimicrobial andantioxidant [11], antifungal [12, 13], anti-fertility activity [14], antinephrolithiasis [15], antiulcer [16], antihyperglycemic [17], anthelmintic activity [18], antiprotozoal [19], anti-complementary [20], wound healing property [21] and cytotoxic [22].

One of the important constituents are flavonoids which are polyphenolic compounds possess a common phenyl benzopyrone structure based on a $\mathrm{C}_{15}\left(\mathrm{C}_{6}-\mathrm{C}_{3}-\mathrm{C}_{6}\right)$ nucleus [23], biosynthesized by phenylpropanoid pathway in response to microbial infection and cannot be biosynthesized by humans and animals, thus the source of flavonoids in animals are of plant origin rather than being biosynthesized in situ. Flavonoids in food are generally responsible for color, taste, prevention of fat oxidation, and protection of vitamins and enzymes [24]. The effectiveness or actions of flavonoids are structure dependent [25]. They have been shown to exert antimicrobial, antiviral, anti-atherosclerosis, cardioprotective, anti-ulcerogenic, cytotoxic, antineoplastic, mutagenic, anti-diabetic, anti-inflammatory, antioxidant, anti-aging, anti-hepatotoxic, antihypertensive, hypolipidemic, antiplatelet [26, 27], neuroprotective and anticonvulsant activities [28].
Several flavonoids had been detected and isolated from different extracts of Melia azedarach. Rutin, quercetin were identified in leaves extract by high-performance thin layer chromatography (HPTLC) method [29], gallic acid, caffeic acid and naringenin were detected in leaves extract by high pressure liquid chromatography (HPLC) [30] while rutin, kaempferol-3-0-robinobioside, kaempferol3-0-rutinoside, and isoquercitrin were isolated from methanolic extract of $M$. azedarach leave by column chromatography [31]. Chlorogenic-conjugates, p-coumaric-conjugates, gentisic-conjugate, kaempferol-conjugates, quercetin-conjugates, chlorogenic acid, kaempferol-3-0- $\beta$-rutinoside,quercetin-3-0- $\beta$-D-glucoside, and rutin were detected in 50\% aquouse ethanol and water extracts from $M$. azedarach leaf by HPLC method [32] acylated quercetin tri glycoside, quercetin-3-O-[rhamnosyl $1 \rightarrow 6\left(4^{\prime \prime}\right.$-lactoyl glucoside)]-4'-O-glucoside, kaempferol-3-O-rutinoside, quercetin-3-O-rutinoside, and the aglycones quercetin and kaempferol were isolated from leaves [33].

The main objective of this study was to investigate the flavonoids and phenolic acids contents of Melia azedarach cultivated in Iraq since there were no previous studies concerning the Iraqi species and also to compare the flavonoids and phenolic acids contents of leaves and fruits.

\section{MATERIALS AND METHODS}

\section{Collection of plant materials}

Melia azedarach leaves and fruits were obtained from Al-mesayab in Babel. The plant was identified and authenticated by Professor Dr. Ali AlMusawy/Department of Biology/College of Sciences/University of Baghdad. A voucher sample was kept at the Department of Pharmacognosy/College of Pharmacy/University of Baghdad.

Equipment and chemicals

The instruments used were rotary evaporator (BÛ̀CHI Rotavapor R205, Swiss), sonicator (Baranson sonifier, USA), HPLC (Shimadzu 
10AV-LC, Japan) and HPTLC (Eike Reich/CAMAG-Laborator, Switzerland).

All chemicals and solvents used were of analytical grade and obtained from Riedel-de Haen, Germany except trifluoroacetic acid and methanol which are HPLC grade purchased from SigmaAldrach, Germany. The standard rutin, kaempferol, quercetin, caffeic acid and chlorogenic acid were purchased from Chengdu Biopurify phytochemicals, China (purity>97). Apigenin, leuteolin, catechine, kamepferol-3-0-glycoside, quercetin-7-0-glycoside, catechin-7-0-glycoside, apegenin-7-0-glycoside, kamepferol-7-0glycoside and catechin-5-0-glycoside standards data were obtained from the database of the HPLC instrument. Thin layer chromatography (TLC) aluminum plates pre-coated with silica gel 60 F 254 (100x $100 \mathrm{~mm}, 0.2 \mathrm{~mm}$ thick) used were obtained from E. Merck Ltd, India.

\section{Extraction}

Leaves and fruits of Melia azedarach were thoroughly washed, dried on the shade for $15 \mathrm{~d}$. The dried plant was powdered in a mechanical grinder. $250 \mathrm{~g}$ of both leaves and fruits powders of Melia azedarach, were individually packed in the thimble of soxhlet apparatus and extracted with $1500 \mathrm{ml}$ of aqueous ethanol (ethanol-water 80:20, $\mathrm{v} / \mathrm{v}$ ) for $12 \mathrm{~h}$. Each extract was filtered and concentrated under vacuum using a rotary evaporator to get a dry residue. $10 \mathrm{~g}$ of each residue was suspended in water and subsequently fractionated by partitioning with petroleum ether, chloroform, ethyl acetate and nbutanol successively using $100 \mathrm{ml} \times 3$ from each solvent. The first three fractions were dried over anhydrous sodium sulfate, filtered and evaporated to dryness under vacuum. $1 \mathrm{~g}$ of n-butanol fraction from each of leaves and fruits extracts were hydrolyzed separately by refluxing with $50 \mathrm{ml}$ of $5 \%$ hydrochloric acid for $6 \mathrm{~h}$, cooled and partitioned with $50 \mathrm{ml} \times 3$ ethyl acetate. The organic layers were combined together, dried over anhydrous sodium sulfate, filtered, and evaporated to dryness.

\section{Preparations of standards and samples for analysis}

Standard solutions for HPLC of rutin, quercetin, kamepferol, were prepared by dissolving $0.04 \mathrm{mg}$ in $1 \mathrm{ml}$ of methanol HPLC grade. Dried samples were prepared for HPLC analysis by dissolving them in methanol and subjecting them to ultrasonication at $60 \%$ duty cycles for $25 \mathrm{~min}$ at $25^{\circ} \mathrm{C}$ followed by centrifugation at $7500 \mathrm{rpm}$ for $15 \mathrm{~min}$. The clear supernatant of each sample was evaporated under vacuum. The residues were resuspended individually, in $1 \mathrm{ml}$ of methanol HPLC grade, homogenizing using vortex mixer, and passing them through $2.5 \mu \mathrm{m}$ disposable filter, and stored at $4^{\circ} \mathrm{C}$ for further analysis. $20 \mu \mathrm{l}$ of the sample was injected into HPLC system for analysis. Standards used for HPTLC analysis (rutin, quercetin, kamepferol, chlorogenic acid and caffeic acid) were prepared by dissolving $1 \mathrm{mg}$ of each standard in $1 \mathrm{ml}$ methanol, while the samples were prepared by dissolving few milligrams from each sample in $1 \mathrm{ml}$ methanol.

\section{Preliminary phytochemical investigation}

Preliminary investigations for the chemical constituents were done using $5 \%$ ethanolic potassium hydroxide $(\mathrm{KOH})$ for detection of flavonoids, Mayers and Dragendorffs reagents for detection of alkaloids, and $1 \%$ ferric chloride $\left(\mathrm{FeCl}_{3}\right)$ for detection of phenolic acids

\section{HPLC analysis}

Ethyl acetate, n-butanol fractions before and after hydrolysis of both parts were analyzed for their flavonoids contents utilizing HPLC separation technique (Shimadzu 10AV-LC), using a mobile phase composed of $0.05 \%$ trifluoroacetic acid in deionized water (solvent A) and solvent B was $0.05 \%$ trifluoroacetic acid in methanol pH 2.5 , gradient program from $0 \%$ B to $100 \%$ B for 15 min with flow rate $1.2 \mathrm{ml} / \mathrm{min}$, wavelength $280 \mathrm{~nm}$, and a column nucludar C-18-DB, 3 $\mu \mathrm{m}$ particle size (50x20 $\mathrm{mmI}$. D).

\section{HPTLC analysis}

Ethyl acetate and n-butanol fractions before and after hydrolysis of both parts were analyzed also for their flavonoids and phenolic acids contents utilizing HPTLC (Eike Reich/CAMAG-Laboratory, Switzerland), using silica gel GF254 plate and a mobile phase composed of organic layer of a mixture of ethyl acetate: acetic acid: formic acid: $\mathrm{H} 20$ (84:4:4:10) and examined at $280 \mathrm{~nm}$ wavelength.

\section{RESULTS}

Preliminary investigations revealed the presence of flavonoids and phenolic compounds in ethyl acetate, $n$-butanol fractions before and after hydrolysis of both parts of plants and absence of alkaloids. The HPLC result of analyzed fractions shows the presence of the following flavonoids which are listed in table 1.

Table 1: Flavonoids content of analyzed ethyl acetate and $\mathbf{n}$-butanol fractions

\begin{tabular}{|c|c|c|c|}
\hline Sample & Ethyl acetate fraction & N-butanol fraction before hydrolysis & N-butanol fraction after hydrolysis \\
\hline Leaves & $\begin{array}{l}\text { quercetin } \\
\text { rutin } \\
\text { catechin } \\
\text { kaempferol } \\
\text { kaempferol-3-0-glycoside } \\
\text { quercetin-7-0-glycoside } \\
\text { apigenin-7-0-glycoside } \\
\text { kaempferol-7-0-glycoside } \\
\text { catechin-5-0-glycoside }\end{array}$ & $\begin{array}{l}\text { quercetin } \\
\text { rutin } \\
\text { apigenin } \\
\text { leuteolin } \\
\text { kaempferol } \\
\text { kaempferol-3-0-glycoside } \\
\text { quercetin-7-0-glycoside } \\
\text { apigenin-7-0-glycoside } \\
\text { kaempferol-7-0-glycoside } \\
\text { catechin-5-0-glycoside }\end{array}$ & $\begin{array}{l}\text { quercetin } \\
\text { apigenin } \\
\text { kaempferol }\end{array}$ \\
\hline Fruit & $\begin{array}{l}\text { quercetin } \\
\text { rutin } \\
\text { leuteolin } \\
\text { catechin } \\
\text { kaempferol } \\
\text { kaempferol-3-0-glycoside } \\
\text { quercetin-7-0-glycoside } \\
\text { apigenin-7-0-glycoside }\end{array}$ & $\begin{array}{l}\text { quercetin } \\
\text { rutin } \\
\text { apigenin } \\
\text { leuteolin } \\
\text { catechin } \\
\text { kaempferol } \\
\text { kamepferol-3-0-glycoside } \\
\text { quercetin-7-0-glycoside } \\
\text { catechin-7-0-glycoside } \\
\text { apigenin-7-0-glycoside } \\
\text { catechin-5-0-glycoside }\end{array}$ & $\begin{array}{l}\text { quercetin } \\
\text { apigenin } \\
\text { catechin } \\
\text { kaempferol }\end{array}$ \\
\hline
\end{tabular}

The HPLC chromatograms of standards and their retention times are shown in fig. 1 and table 2 respectively 


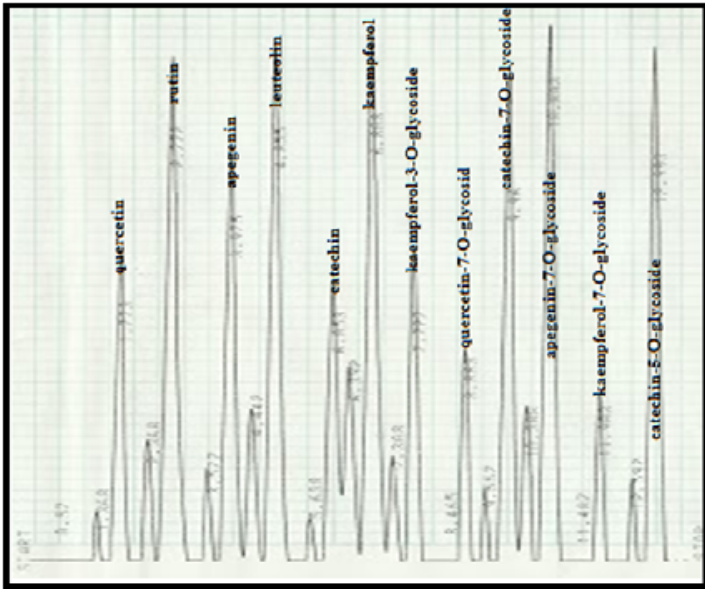

Fig. 1: HPLC chromatogram showing the retention time of standard flavonoids

Table 2: Retention time in minutes of standard flavonoids

\begin{tabular}{ll}
\hline Standard materials & Retention time in minutes \\
\hline Quercetin & 1.77 \\
Rutin & 2.77 \\
Apigenin & 3.97 \\
Leuteolin & 4.85 \\
Catechin & 6.05 \\
Kaempferol & 6.8 \\
Kaempferol-3-0-glycoside & 7.72 \\
Quercetin-7-0-glycoside & 8.86 \\
Catechin-7-0-glycoside & 9.96 \\
Apigenin-7-0-glycoside & 10.8 \\
Kaempferol-7-0-glycoside & 11.9 \\
Catechin-5-0-glycoside & 12.99
\end{tabular}

The HPLC chromatograms of ethyl acetate fractions of the leaves and fruits are shown in fig. 2 and 3 respectively. The retention times of these fractions are shown in table 3 .

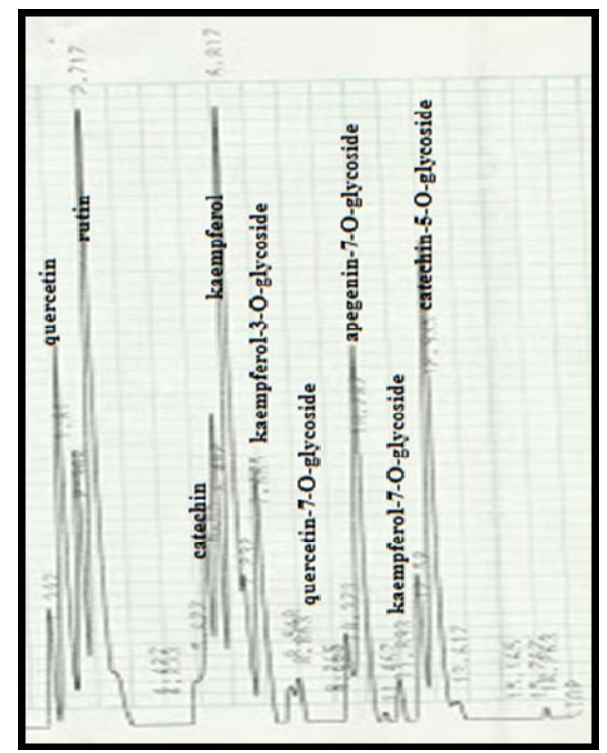

Fig. 2: HPLC chromatogram of ethyl acetate fraction of the leaves

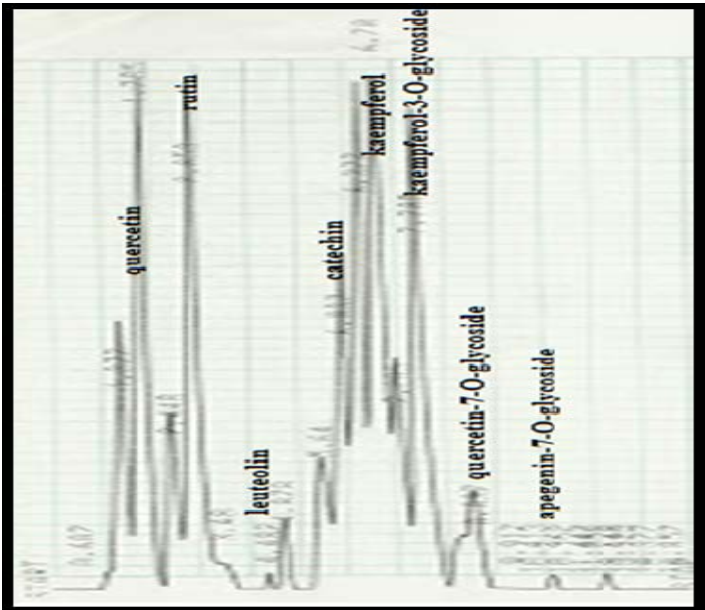

Fig. 3: HPLC chromatogram of ethyl acetate fraction of the fruits

The HPLC chromatograms of n-butanol fractions before hydrolysis of both leaves and fruits are shown in fig. 4 and 5 respectively and their retention time are shown in table 4.

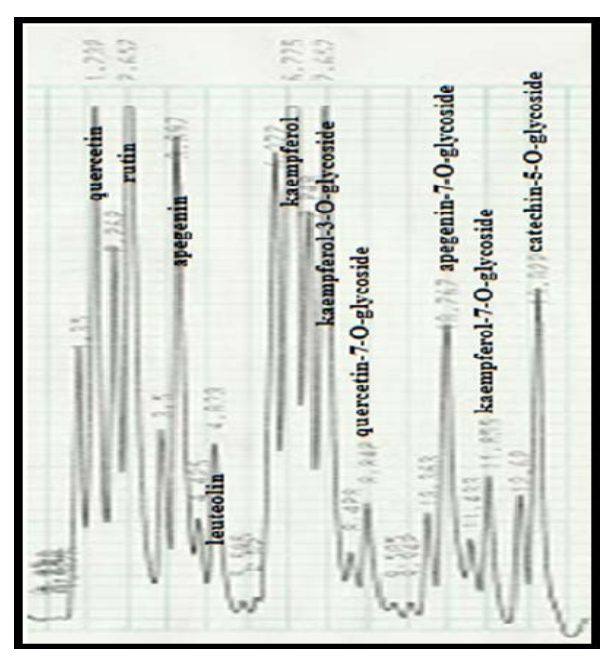

Fig. 4: HPLC chromatogram of $n$-butanol fraction of leaves before hydrolysis

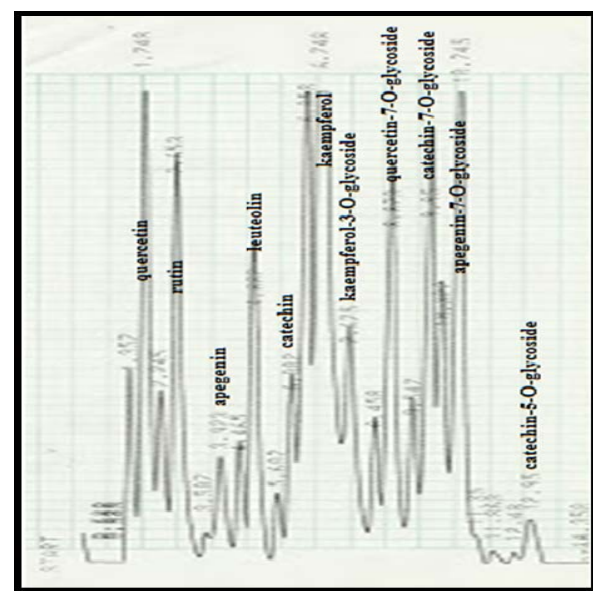

Fig. 5: HPLC chromatogram of n-butanol fraction of fruits before hydrolysis 
Table 3: Retention time in minutes of flavonoids of ethyl acetate fraction of leaves and fruits

\begin{tabular}{|c|c|c|c|}
\hline Flavonoid & $\begin{array}{l}\text { Retention time of } \\
\text { standards }\end{array}$ & $\begin{array}{l}\text { Retention time for flavonoids in ethyl acetate } \\
\text { fraction of leaves }\end{array}$ & $\begin{array}{l}\text { Retention time for flavonoides in ethyl } \\
\text { acetate fraction of fruits }\end{array}$ \\
\hline Quercetin & 1.77 & 1.81 & 1.78 \\
\hline Rutin & 2.77 & 2.717 & 2.85 \\
\hline Apigenin & 3.97 & ----- & ----- \\
\hline Ieuteolin & 4.85 & ----- & 4.878 \\
\hline Catechines & 6.05 & 6.06 & 6.03 \\
\hline Kaempferol & 6.80 & 6.817 & 6.78 \\
\hline $\begin{array}{l}\text { Kaempferol-3-0- } \\
\text { glycoside }\end{array}$ & 7.72 & 7.665 & 7.705 \\
\hline $\begin{array}{l}\text { Quercetin-7-0- } \\
\text { glycoside }\end{array}$ & 8.86 & 8.863 & 8.837 \\
\hline $\begin{array}{l}\text { Catechin-7-0- } \\
\text { glycoside }\end{array}$ & 9.96 & ----- & ---- \\
\hline $\begin{array}{l}\text { Apigenin-7-0- } \\
\text { glycoside }\end{array}$ & 10.80 & 10.787 & 10.962 \\
\hline $\begin{array}{l}\text { Kaempferol-7-0- } \\
\text { glycoside }\end{array}$ & 11.90 & 11.893 & ----- \\
\hline $\begin{array}{l}\text { Catechin-5-0- } \\
\text { glycoside }\end{array}$ & 12.99 & 12.935 & ----- \\
\hline
\end{tabular}

Table 4: Retention time in minutes of flavonoids of $n$-butanol fractions before hydrolysis of leaves and fruits

\begin{tabular}{|c|c|c|c|}
\hline Flavonoids & $\begin{array}{l}\text { Rention time of } \\
\text { standards }\end{array}$ & $\begin{array}{l}\text { Retention time for flavonoids in normal } \\
\text { butanol fraction before hydrolysis of leaves }\end{array}$ & $\begin{array}{l}\text { Retention time for flavonoids in normal } \\
\text { butanol fraction before hydrolysis of fruits }\end{array}$ \\
\hline Quercetin & 1.77 & 1.73 & 1.748 \\
\hline Rutin & 2.77 & 2.657 & 2.653 \\
\hline Apigenin & 3.97 & 3.897 & 3.923 \\
\hline Leuteolin & 4.85 & 4.833 & 4.882 \\
\hline Catechine & 6.05 & ----- & 6.002 \\
\hline Kaempferol & 6.80 & 6.775 & 6.748 \\
\hline $\begin{array}{l}\text { Kaempferol-3-0- } \\
\text { glycoside }\end{array}$ & 7.72 & 7.657 & 7.675 \\
\hline $\begin{array}{l}\text { Quercetin-7-0- } \\
\text { glycoside }\end{array}$ & 8.86 & 8.842 & 8.873 \\
\hline $\begin{array}{l}\text { Catechin-7-0- } \\
\text { glycoside }\end{array}$ & 9.96 & ----- & 9.95 \\
\hline $\begin{array}{l}\text { Apigenin-7-0- } \\
\text { glycoside }\end{array}$ & 10.80 & 10.767 & 10.745 \\
\hline $\begin{array}{l}\text { Kaempferol-7-0- } \\
\text { glycoside }\end{array}$ & 11.90 & 11.855 & ----- \\
\hline $\begin{array}{l}\text { Catechin-5-0- } \\
\text { glycoside }\end{array}$ & 12.99 & 13.022 & 12.95 \\
\hline
\end{tabular}

The HPLC chromatograms for flavonoids of n-butanol fractions of leaves and fruits after hydrolysis are shown in fig. 6 and 7 respectively and their retention times in table 5.

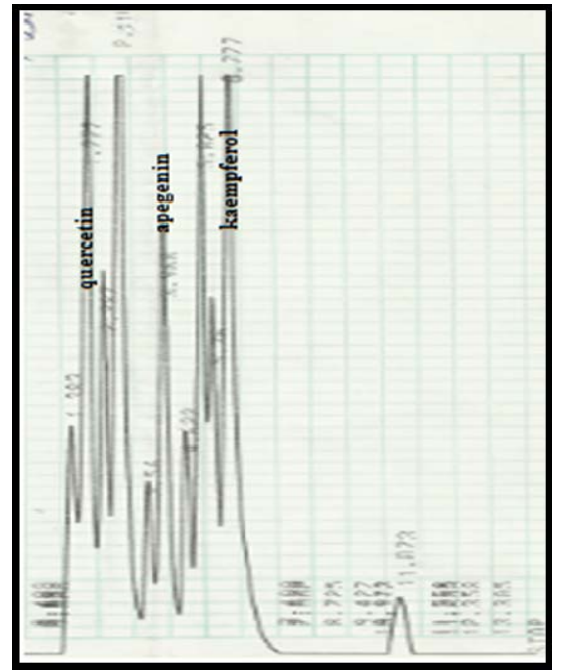

Fig. 6: HPLC chromatogram of n-butanol fraction of leave after hydrolysis

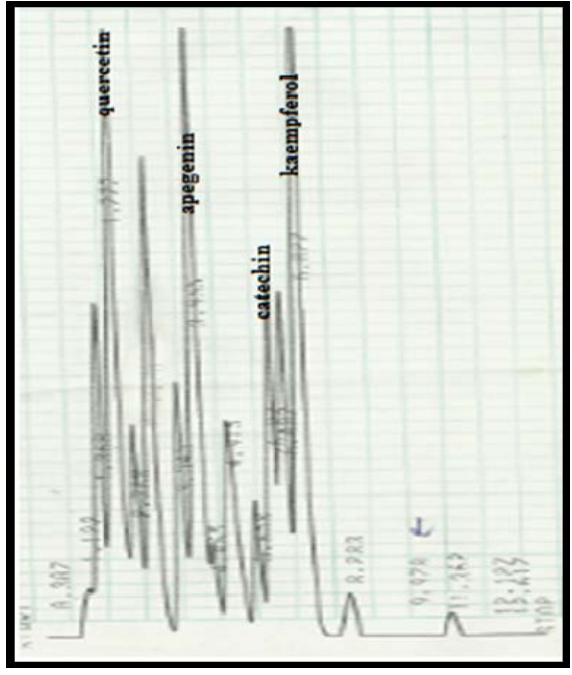

Fig. 7: HPLC chromatogram of n-butanol fraction of fruit after hydrolysis 
Table 5: Retention times in minutes for flavonoids of $\mathbf{n}$-butanol fraction of leaves and fruits after hydrolysis

\begin{tabular}{|c|c|c|c|}
\hline Flavonoids & $\begin{array}{l}\text { Rention time of } \\
\text { standards }\end{array}$ & $\begin{array}{l}\text { Retention time for flavonoids in normal } \\
\text { butanol fraction after hydrolysis of leaves }\end{array}$ & $\begin{array}{l}\text { Retention time for flavonoids in normal } \\
\text { butanol fraction after hydrolysis of fruits }\end{array}$ \\
\hline Quercetin & 1.77 & 1.777 & 1.777 \\
\hline Rutin & 2.77 & ---- & ---- \\
\hline Leuteolin & 4.85 & ---- & ---- \\
\hline Catechines & 6.05 & ---- & 6.07 \\
\hline Kaempferol & 6.80 & 6.777 & 6.827 \\
\hline $\begin{array}{l}\text { Kaempferol-3-0- } \\
\text { glycoside }\end{array}$ & 7.72 & ----- & ---- \\
\hline $\begin{array}{l}\text { Quercetin-7-0- } \\
\text { glycoside }\end{array}$ & 8.86 & ---- & ---- \\
\hline $\begin{array}{l}\text { Catechin-7-0- } \\
\text { glycoside }\end{array}$ & 9.96 & ---- & ---- \\
\hline $\begin{array}{l}\text { Apigenin-7-0- } \\
\text { glycoside }\end{array}$ & 10.80 & ---- & ---- \\
\hline $\begin{array}{l}\text { Kamepferol-7-0- } \\
\text { glycoside }\end{array}$ & 11.90 & $---\cdot$ & ---- \\
\hline $\begin{array}{l}\text { Catechin-5-0- } \\
\text { glycoside }\end{array}$ & 12.99 & ---- & ---- \\
\hline
\end{tabular}

HPTLC analysis results of both leaves and fruits different extracts contents of flavonoids and phenolic acids as compared with standards are shown in table 6.

Table 6: The flavonoids and phenolic acids contents of different extracts of leaves and fruits

\begin{tabular}{llll}
\hline Sample & Ethyl acetate fraction & N-butanol fraction before hydrolysis & N-butanol fraction after hydrolysis \\
\hline Leaves & rutin & Rutin & Quercetin \\
& chlorogenic acid & chlorogenic acid & caffeic acid \\
& kamepferol & kamepferol & kamepferol \\
& quercetin & & Quercetin \\
Fruits & rutin & Rutin & caffeic acid \\
& chlorogenic acid & chlorogenic acid & kamepferol \\
& kamepferol & kamepferol & \\
\hline
\end{tabular}

HPTLC results of standard flavonoids, phenolic acids and the analyzed fractions are shown in fig. 8 and fig. 9.

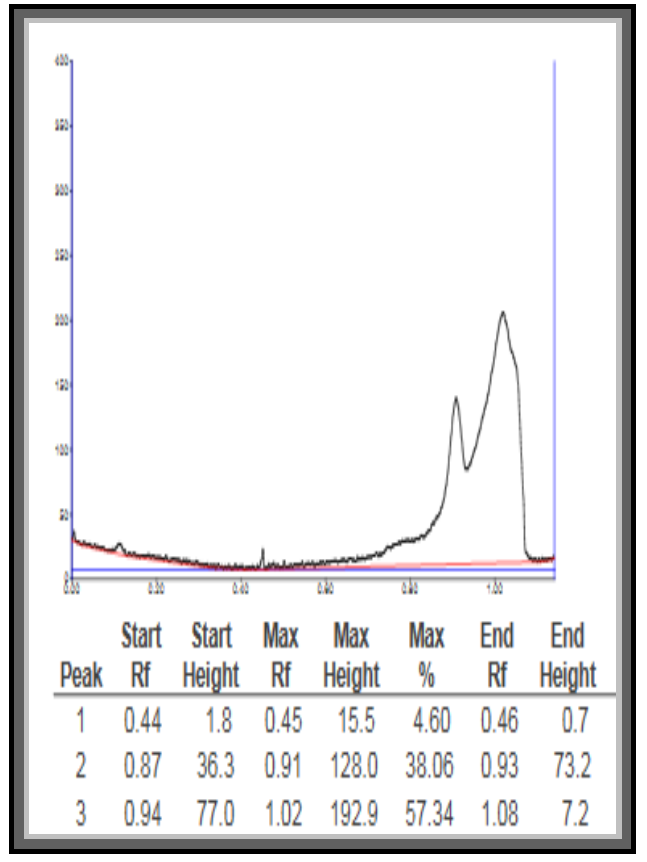

Track 1: Quercetin standard

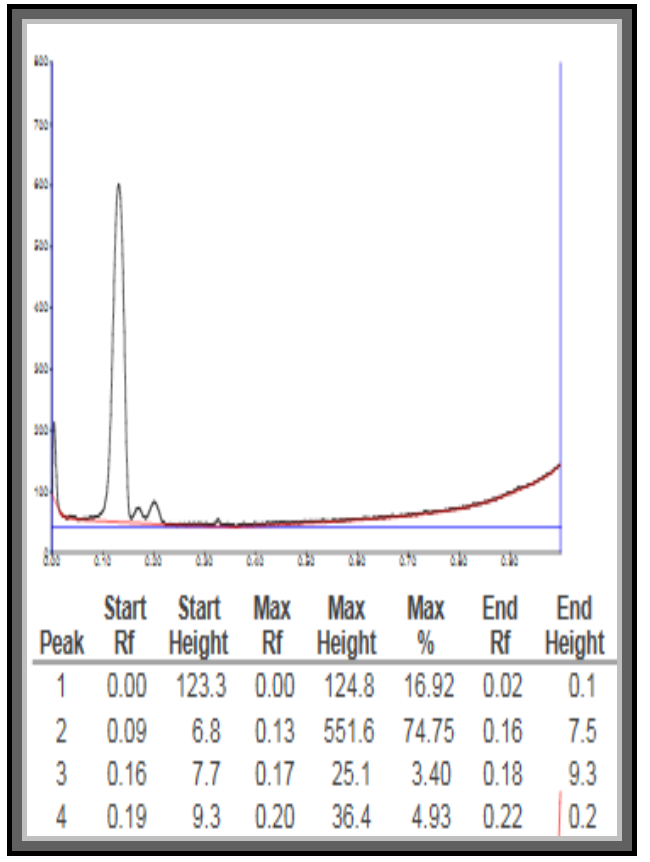

Track 2: Rutin standard 


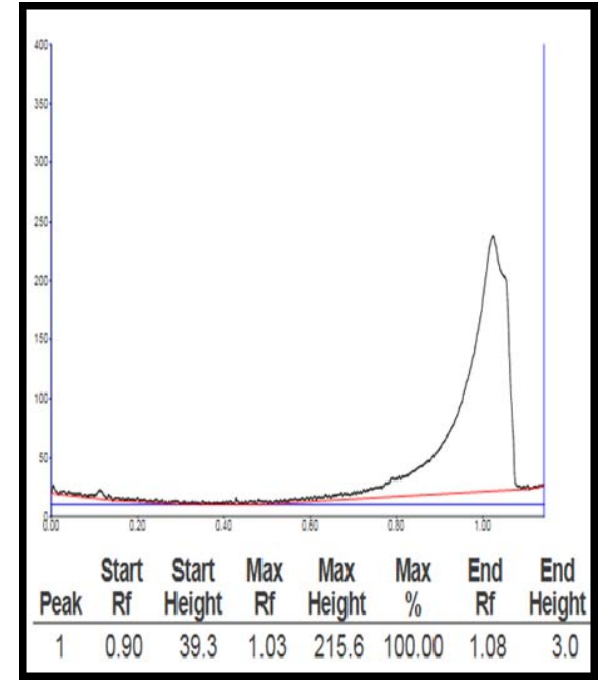

Track 3: Kaempferol standard

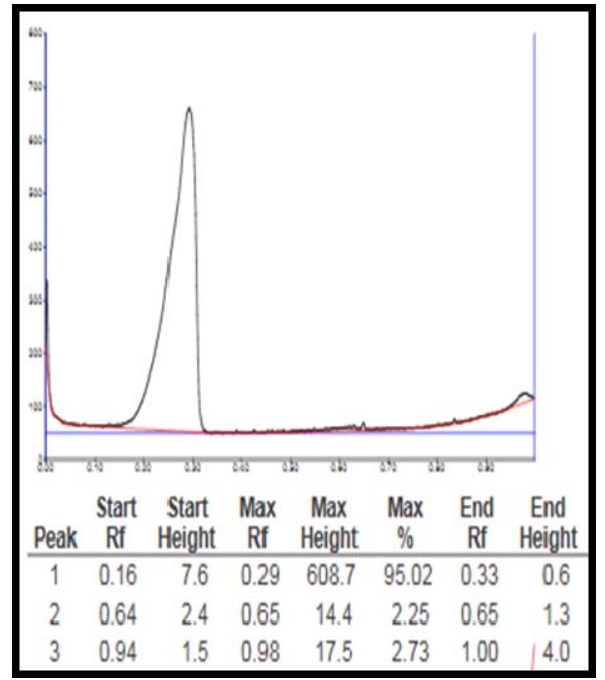

Track 4: Chlorogenic acid standard

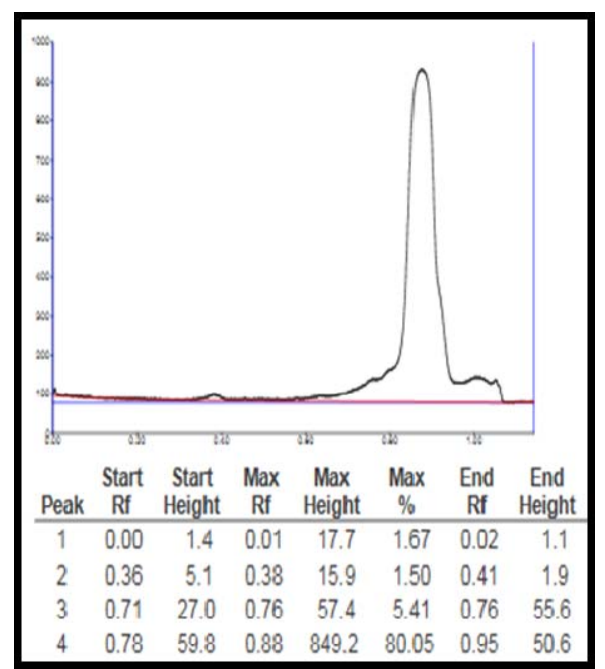

Track 5: Caffeic acid standard

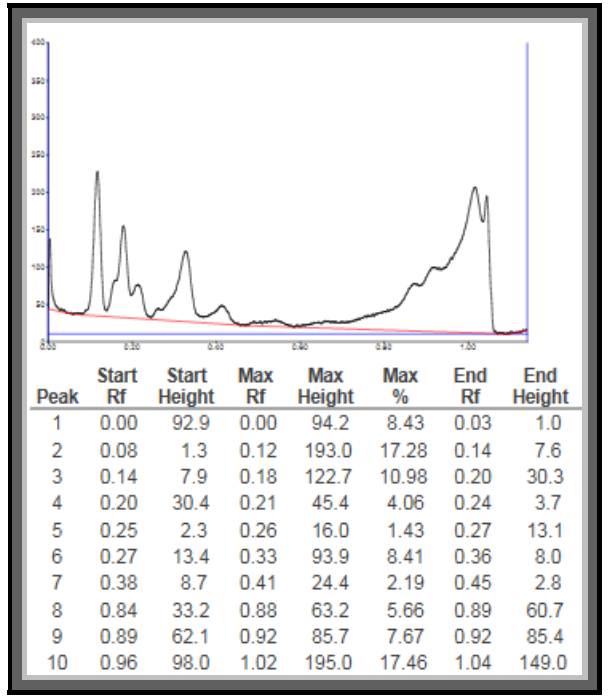

Track 6: Ethyl acetate fraction of leaves

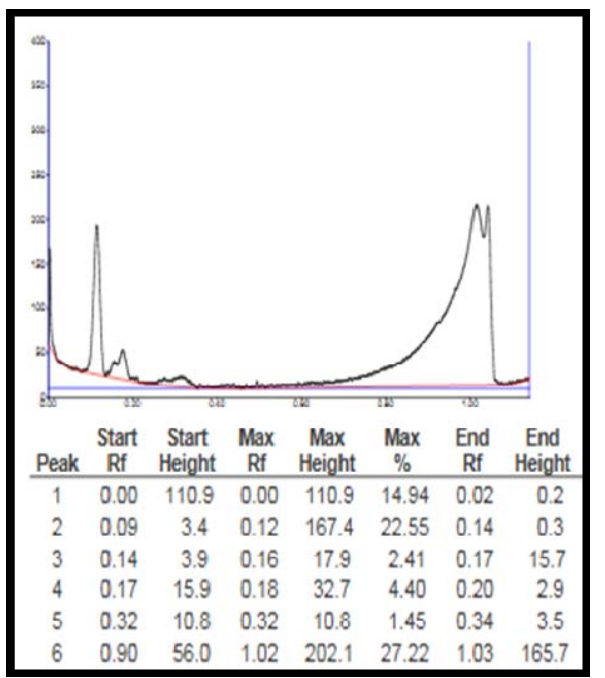

Track 7: N-butanol fraction of leaves before hydrolysis

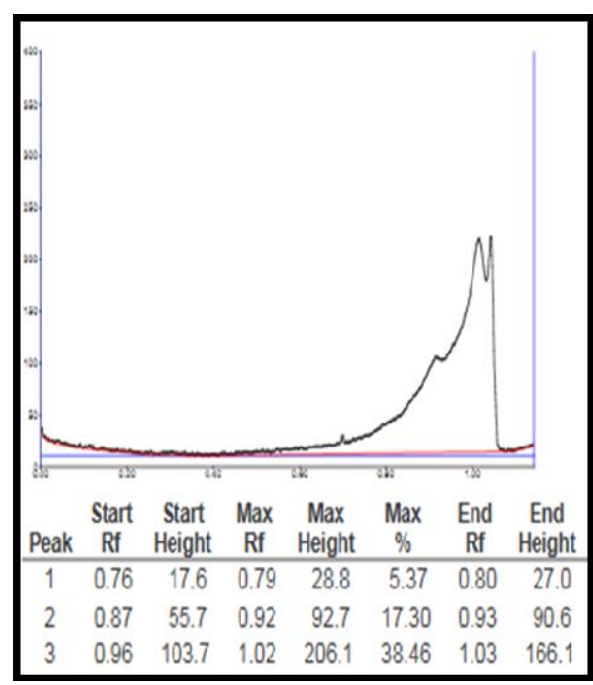

Track 8: N-butanol fraction of leave after hydrolysis 


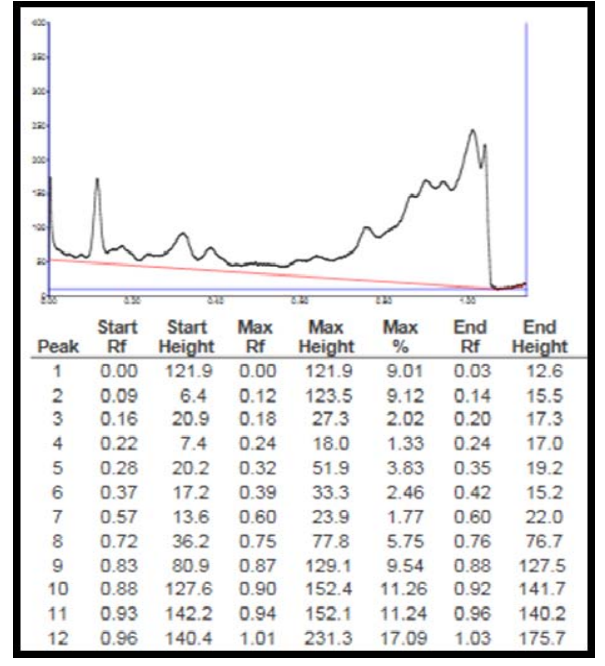

Track 9: Ethyl acetate fraction of fruits

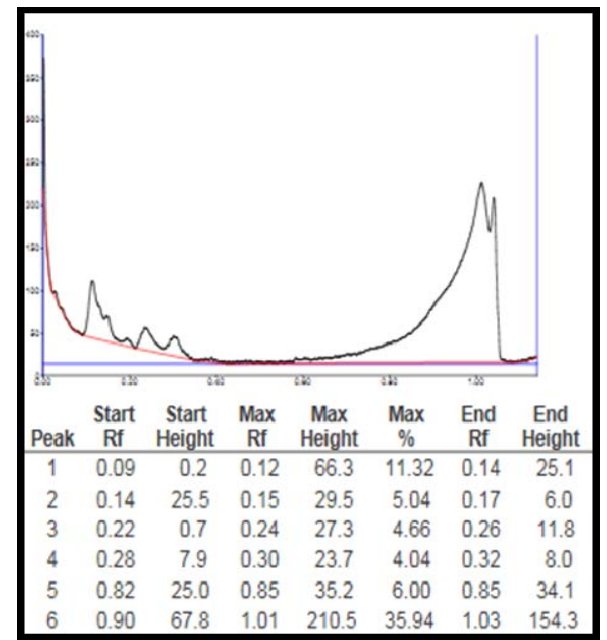

Track 10: N-butanol fraction of fruit before hydrolysis

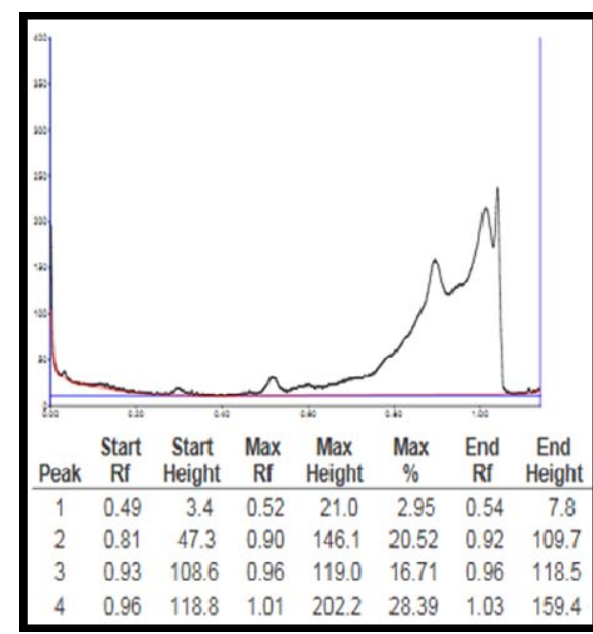

Track 11: N-butanol fraction of fruit after hydrolysis

Fig. 8: HPTLC chromatograms showing end retardation factor values of standard flavonoids, phenolic acids and analyzed fractions

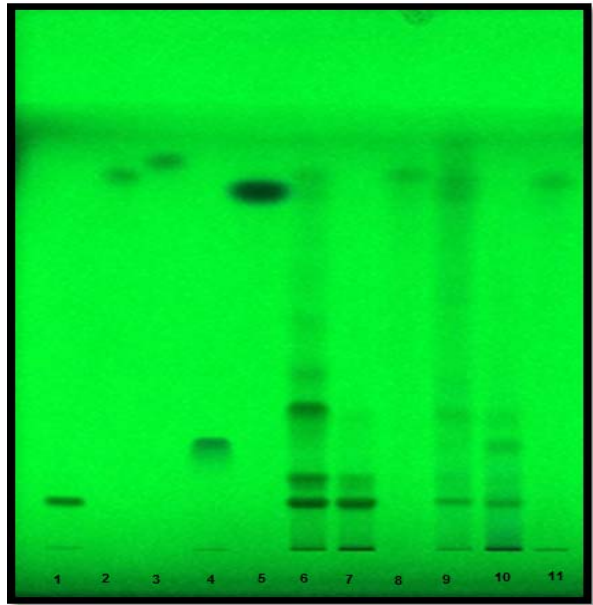

(a) HPTLC chromatogram at $254 \mathrm{~nm}$

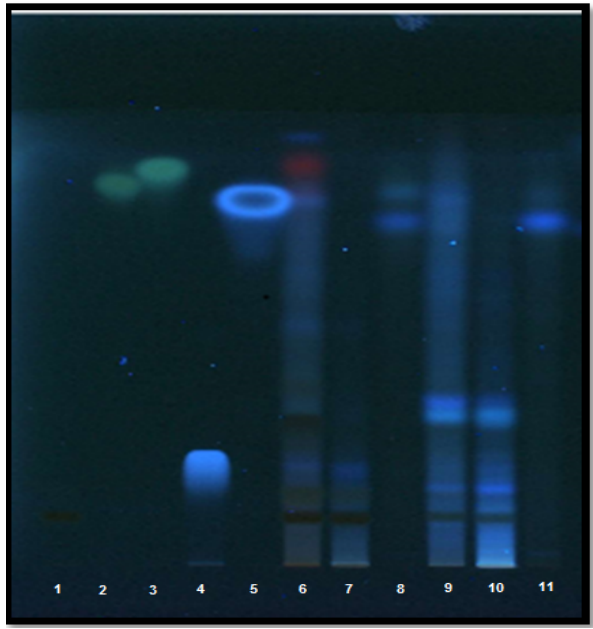

(b) HPTLC chromatogram at $366 \mathrm{~nm}$

Fig. 9: ( $a$ and b) HPTLC plates of analyzed fractions with reference standards, detection under UV light at $254 \mathbf{~} \mathbf{m}$ and $366 \mathrm{~nm}$ (1: rutin, 2: quercetin, 3: kamepferol, 4: chlorogenic acid, 5: caffeic acid, 6: ethyl acetate fraction of leaves, $7: \mathbf{n}$ butanol fraction of leaves before hydrolysis, 8: n-butanol fraction of leaves after hydrolysis, 9: ethyl acetate fraction of fruits, 10: n-butanol fraction of fruit before hydrolysis, 11: nbutanol fraction of fruits after hydrolysis)

\section{DISCUSSION}

The HPLC results revealed few differences between the flavonoids contents between the leaves and the fruits in both forms as aglycones and as glycosides. The n-butanol fraction revealed the presence catechin-7-0-glycoside in fruit only. Catechin had been detected in the fruits of Melia azedarach by HPLC but not the Iraqi species. [7] Kaempferol-7-0-glycoside was found in the leaves only, catechin was found as aglycone in the ethyl acetate fraction and in two forms of glycosides in an n-butanol fraction of fruits i.e. 5 and 70 -glycoside, while in ethyl acetate fraction of leaves it was found as aglycone and in one type of glycoside which 5-0-glycoside only. From the above-mentioned results, we can conclude that catechin and its glycosides are more abundant in the fruits than in the leaves.

The HPTLC results revealed that kaempferol are present in all fractions of leaves and fruits which indicate the presence of kaempferol as aglycone and as glycosides, this explains the presence of kaempferol in the n-butanol after hydrolysis fraction. Kaempferol, Kaempferol-3-0-robinobioside, Kaempferol-3-0-rutinoside had been 
isolated from leaves of Melia azedarach by column chromatography, $[31,33]$ and also detected in fruits by HPLC but not the Iraqi species. [7] Quercetin detection in $\mathrm{n}$. butanol after hydrolysis fraction could be due to hydrolysis of rutin (quercetin-3-rutinoside) and other quercetin glycosides. Chlorogenic acid is found in both leaves and fruits. caffeic acid, chlorogenic acid, rutin; quercetin were detected in leave by HPLC [30]

Caffeic acid detected in $\mathrm{n}$. butanol after hydrolysis since chlorogenic acid is an ester of caffeic acid with quinic acid, so it has been formed after the hydrolysis of chlorogenic acid [34].

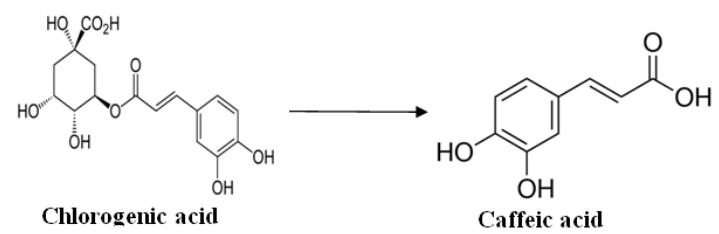

These differences could be attributed to the differences in the biochemical reactions which are affected by the availability of enzymes, cofactors and other biochemical factors required.

This is the first phytochemical investigation done in Iraq concerning Melia azedarach and also the first study was done concerning the comparison between flavonoids and phenolic acids contents of leaves and fruits of this plant. Further steps are needed to be done to isolate the different chemical constituents detected.

\section{CONCLUSION}

No major differences were found between the flavonoids and phenolic acids contents of the leaves and fruits of Melia azedarach. The main differences found are the presence catechin-7-0-glycoside in fruit only, while kaempferol-7-0-glycoside is found in the leaves only, and catechin and its glycosides are more abundant in the fruits than in the leaves.

\section{ACKNOWLEDGMENT}

We are deeply grateful to the college of pharmacy/university of Baghdad for giving us the opportunity and facilities to achieve this work.

\section{CONFLICT OF INTERESTS}

Declared none

\section{REFERENCES}

1. Jafari S, Saeidnia S, Hajimehdipoor H, Ardekani M, Mohammad Ali F, Hadjiakhoondi A, et al. Evaluation of physicochemical and phytochemical properties of Melia Azedarach. leaves (Family: Meliaceae). Int J Pharm Pharm Sci 2013;5:104-7.

2. Huma Q, Muhammad A, Abida A, Naveed Iqbal R, Sammer F, Muhammad Shoaib A. Ethnopharmacological and phytochemical account of paradise tree (Melia azedarach L.: Meliaceae). Pure Appl Biol 2016;5:5-14.

3. Beauty AR, Nur Kabidul Azam Md, Abdul Mannan Md, Nasir Ahmed Md, Nazmul Hasan Md. Phytochemistry and pharmacological appraisals of persian lilac (Melia azedarachLinn). Ajethno 2014;1:152-63.

4. Kumar R, Singh R, Meera RS, Kalidhar SB. Chemical components and insecticidal properties of bakyain (Melia azedarach L.). Agric Rev 2003;24:101-15.

5. Sunita B. Phytochemical screening and evaluation of its repellent activity of Melia azedarach L. Indo Am J Pharm Res 2013;3:4310-8.

6. Suresh K, Deepa P, Harisaranraj R, Vaira AV. Antimicrobial and phytochemical investigation of the leaves of Carica papaya L., Cynodon dactylon L. Pers., Euphorbia hirta L., Melia azedarach L. and Psidium guajava L. Ethnobotanical Leaflets 2008;12:1184-91.

7. Italo Chiffelle G, Amanda Huerta F, Diego Lizana R. Physical and chemical characterization of Melia azedarach L. fruit and leaf for use as a botanical insecticide. Agric Res 2009;69:39-45.
8. Gebreamkak A, Azerefegne F. Insecticidal activity of chinaberry, endod and pepper tree agains the maize stalk borer (Lepidoptera: Noctuidae) in Southern Ethiopia. Int J Pest Manage 1999;45:9-13.

9. Sultana S, Akhtar N, Asif HM. Phytochemical screening and antipyretic effects of hydromethanol extract of Melia azedarach leaves in rabbits. Bangladesh J Pharmacol 2013;8:214-7.

10. Petrera E, Coto CE. Effect of the potent antiviral 1-cinnamoyl3,11-dihydroxymeliacarpin on cytokine production by murine macrophages stimulated with HSV-2. Phytother Res 2014;28:104-9.

11. Pokhrel B, Sulav R, Sagar R. Phytochemical screening, antimicrobial and antioxidant activity of Melia azedrachta in methanol solvent. World J Pharm Pharm Sci 2015;4:1562-75.

12. Jabeen K, Javaid A, Ahmad E, Athar M. Antifungal compounds from Melia azedarach leaves for management of ascochytarabiei, the cause of chickpea blight. See comment in PubMed Commons belowNat Prod Res 2011;25:264-76.

13. Khan IH, Arshad J. Antifungal activity of Melia azedarach Linn fruit extract against Sclerotium rolfsii, the cause of collar rot disease of chickpea. Mycopath 2013;11:9-13.

14. Vijay Kumar R, Venkat Raji Reddy G, Sathyanarayana J, Bikshapathi T, Krishna Reddy M. Effect of Melia azedarach and Dodonaea viscose aqueous leaf extracts on fertility in male albino rats. Indian J Pharm Biol Res 2013;1:7-12.

15. Nagiat HT, Fathi AH, Sumalatha G, Fauzi EM, Babu Rao C, Prakash K. Study on antiurolithiatic activity of Melia azadirachta L. aqueous extract in rats. Afr J Plant Sci 2014;2:27-31.

16. Yogendr B, Kalpana P, Mohan S, Maniyari R, Sunil J, Sampada U. aAntiulcer activity of Melia azedarach Linn in aspirin induced and pylorus ligated rats. J Pharm Res 2009;2:1456-9.

17. Prashant K, Raghuveer I, Rubina L, Verma A, Kusum S, Vinita A. Antihyperglycemic effect of leaves of Melia azedrach on alloxan induced diabetic rat. IGPPRI 2014;5:1121-4.

18. Cala AC, Chagas A, Oliveira MC, Matos AP, Borges LM, Sousa LA, et al. In vitro anthelmintic effect of Melia azedarach L. and Trichilia claussenii $\mathrm{C}$. against sheep gastrointestinal nematodes. Exp Parasitol 2012;130:98-102.

19. Lee YS, IB Chung, Choi WH, Cho YJ, Chu JP, BI Min, et al. Inhibitory effects of Melia azedarach L. extracts on the growth of Trichomonus vaginalis ultrastructural changes of Trichomonus vaginalis by Melia azedarach L. J Protozool Res 2007;17:16-24.

20. Courrèges MC, Massouh EJ, Coulombié FC. Effect of Melia azedarach L. leaf extracts on human complement and polymorphonuclear leukocytes. J Ethnopharmacol 1994;41:53-7.

21. Veda Vidya T, Srinivasan D, Sengottuvelu S. Wound healing potential of Melia azedarach L. leaves in alloxan induced diabetic rats. GJRMI 2012;1:265-71.

22. Ntall NG, Cottiglia F, Bueno CA, Alché LE, Leonti M, Vargiu S, et al. Cytotoxic tirucallane triterpenoids from Melia azedarach fruits. Molecules 2010;15:5866-77.

23. Sisa M, Bonnet SL, Ferreira D, Van der Westhuizen JH. Photochemistry of flavonoids. Molecules 2010;15:5196-245.

24. Shashank K, Abhay PK. Chemistry and biological activities of flavonoids. Sci World J 2013;2013:1-16.

25. Kelly EH, Anthony RT, Dennis JB. Flavonoid antioxidants: chemistry, metabolism and structure-activity relationships. J Nutr Biochem 2002;13:572-84.

26. Permender R, Hema C, Sushila R, Dharmender R, Vikash K, Kanchan K. Mechanism of action of flavonoids as antiinflammatory agents. Inflammation Allergy Drug Targets 2009;8:229-35.

27. Bhattacharya S, Maity S, Pramnaick D, Hazra AK, Choudhury M. HPLC of a phenolic compound, antioxidant and antimicrobial activity of bulbs from three ornithagalum species available in India. Int J Pharm Pharm Sci 2016;8:187-92.

28. Hamad MN, Sulaiman AA, Numan IT, Abdul Razak SA. Study of the anticonvulsant effect of ethyl acetate fraction of Matricaria recutita extract in mice. Int J Pharm Pharm Sci 2014;6:224-7.

29. Srinivasa RA, Mohammed Fazil A. Simultaneous estimation of quercetin and rutin in ethanolic extract of Melia azedarach Linn leaves by HPTLC method. Asian J Biochem Pharm Res 2013;3:56-9. 
30. Vijayanand S, Wesely EG. Phytochemical studies of Melia azedrach and Murryaya koeingi. Int J Pharma Sci Res 2011;2:1298-302.

31. Samineh J, Soodabeh S, Homa H, Mohammad Reza Shams A, Mohammad Ali F, Abbas H, et al. Cytotoxic evaluation of Melia azedarach in Comparison with, Azadirachta Indica and its phytochemical investigation. Daru 2013;21:1-7.

32. Aoudia H, Oomah BD, Zaidi F, Zaidi-Yahiaoui R, Drover J CG, Harrison JE. Phenolics, antioxidant and anti-inflammatory activities of Melia azedarach extracts. Int J Appl Res Nat Prod 2013;6:19-29.

33. SalibAffiliated withChemistry of Tanning Materials and Leather Technology, National Research Centre, Dokki JY, MichaelAffiliated withChemistry of Tanning Materials and Leather Technology, National Research Centre, Dokki Email author HN, El-Nogoumy SI.
New lactoyl glycoside quercetin from Melia Azedarach leaves. Chem Nat Compd 2008;44:13-5.

34. Raimondi S, Anighoro A, Quartieri A, Amaretti A, TomásBarberán FA, Rastelli G, et al. Role of bifidobacteria in the hydrolysis of chlorogenic acid. Microbiologyopen 2015; 4:41-52.

\section{How to cite this article}

- $\quad$ Noor S Jaafar, Maha N Hamad, Ibrahim S Abbas, Iman S Jaafar. Qualitative phytochemical comparsion between flavonoids and phenolic acids contents of leaves and fruits of Melia azedarach (Family: meliaceae) cultivated in iraq by HPLC and HPTLC. Int J Pharm Pharm Sci 2016;8(10):242-250. 